\title{
The Effect of Different Dissolved Oxygen Tensions on Growth and Enzyme Activities of Campylobacter sputorum subspecies bubulus
}

\author{
By H. G. D. NIEKUS, WYTSKE DE VRIES \\ AND A. H. STOUTHAMER \\ Microbiology Department, Biological Laboratory, Free University, \\ De Boelelaan 1087, Amsterdam, The Netherlands
}

(Received 17 June 1977)

Campylobacter sputorum subspecies bubulus was grown in batch cultures in which the dissolved oxygen tension (d.o.t.) was maintained at various constant levels. At a range of d.o.t. from 0.002 to $0.05 \mathrm{~atm}$, which allowed good growth (mean generation time approximately $\mathrm{I} \cdot 5 \mathrm{~h}$ ), L-lactate was preferentially consumed before D-lactate. L-Lactate oxidation was accompanied by equimolar acetate production during exponential growth. A value for $Y_{\text {L-lactate }}$ (g dry weight bacteria per mol L-lactate) of 54 was determined. Net acetate production stopped when $C$. sputorum started to use D-lactate after consumption of L-lactate. When a culture growing exponentially at the expense of L-lactate was shifted from a d.o.t. of $0.02 \mathrm{~atm}$ to a d.o.t. of $0.15 \mathrm{~atm}$, growth was impaired, and L-lactate consumption and corresponding acetate production diminished. This decrease correlated with a loss of lactate dehydrogenase activity after the shift. Campylobacter sputorum appeared to possess cytochromes of the $b$ - and $c$-type and a carbon monoxide-binding pigment. Evidence is given that the principal site of oxygen damage is lactate dehydrogenase rather than the cytochrome chain.

\section{INTRODUCTION}

The genus Campylobacter contains vibrios that differ from those in the genus Vibrio with regard to the base composition of their deoxyribonucleic acid (Sebald \& Véron, 1963). Important characteristics of Campylobacter strains are their inability to ferment carbohydrates and their obligate microaerophilism when oxygen is the terminal electron acceptor. Campylobacter sputorum subsp. bubulus, the organism used in this study, is catalasenegative, and most of the strains tested grow optimally on agar slants in an atmosphere containing 25 to $50 \%$ air, $10 \% \mathrm{CO}_{2}$ and $\mathrm{H}_{2}$ (Loesche, Gibbons \& Socransky, 1965). This organism can grow anaerobically with nitrate, fumarate or malate. It contains a soluble hydrogenase, and is able to use $\mathrm{H}_{2}$ as energy source, but is not dependent on $\mathbf{H}_{2}$ for anaerobic growth (Syed \& Loesche, I97I; van Palenstein Helderman \& Rosman, 1976).

A study of Spirillum volutans, an obligate microaerophilic bacterium, revealed a possible role of the tricarboxylic acid cycle enzymes fumarate hydratase and malate dehydrogenase as the primary sites of oxygen damage (Cole, 1973). Succinate is the main electron donor for the respiratory chain of $S$. volutans and because of the low succinate dehydrogenase activity this bacterium is not very well protected against oxygen entering the cell (Cole \& Rittenberg, I97I). Recently Bowdre et al. (1976) reported that the addition of ferric ionbinding dihydroxyphenyl compounds to the growth medium allowed $S$. volutans and Campylobacter fetus subsp. jejuni to grow at higher oxygen tensions than in the absence of these compounds. In the case of C. fetus, an increase in the iron content of the medium also 
allowed growth at $2 \mathrm{I} \% \mathrm{O}_{2}$. The authors concluded that the microaerophilic nature of these organisms could, at least partially, be explained by an assumed inability to produce enough ferric ion-binding compounds to support aerobic growth.

In the present study, $C$. sputorum subsp. bubulus was cultured in a complex medium supplemented with lactate, and the effect of changing the dissolved oxygen tension (d.o.t.) on growth rate and various enzyme activities was determined. The results obtained point to lactate dehydrogenase as the primary site of oxygen damage. A preliminary report of this investigation has already been published (Niekus, de Vries \& Stouthamer, 1977).

\section{METHODS}

Organism and growth conditions. Campylobacter sputorum subsp. bubulus strain 9977 was kindly supplied by Dr W. H. van Palenstein Helderman, State University, Utrecht, The Netherlands, who obtained it from Dr W. J. Loesche, Department of Oral Biology, University of Michigan, School of Dentistry, Ann Arbor, Michigan, U.S.A. The organism was maintained on agar slants of thioglycollate medium (U.S.P.) supplemented with I $\mathrm{g} \mathrm{KNO}_{3} 1^{-1}$. After incubation for $24 \mathrm{~h}$ at $37^{\circ} \mathrm{C}$ in a BBL GasPak-jar, the slants were stored at $4{ }^{\circ} \mathrm{C}$ in an anaerobic jar in an atmosphere of $\mathrm{N}_{2}$ plus $5 \% \mathrm{CO}_{2}$. Bacteria were grown at $37^{\circ} \mathrm{C}$ in a medium (TL) containing (per l) $26 \mathrm{~g}$ tryptose broth, $1 \mathrm{~g} \mathrm{MgCl} 2.6 \mathrm{H}_{2} \mathrm{O}$, $10 \mathrm{mg} \mathrm{FeCl} 3.6 \mathrm{H}_{2} \mathrm{O}$ and $3 \mathrm{~g} \mathrm{Na}$ DL-lactate solution (about $60 \%, \mathrm{w} / \mathrm{w}$ ). The medium was buffered at $\mathrm{pH} 6.8$ with $0.01 \mathrm{M}$-sodium potassium phosphate. In experiments where the $\mathrm{FeCl}_{3} .6 \mathrm{H}_{2} \mathrm{O}$ concentration was $0.6 \mathrm{~g} \mathrm{l}^{-1}$, the phosphate buffer was omitted and replaced by $N, N$-bis(2-hydroxyethyl)-2-aminoethane sulphonic acid (BES) at $1.07 \mathrm{~g} \mathrm{l}^{-1}$. These alterations did not influence the growth rate. Experiments were performed in a 21 vessel (Biolafitte, France) through which air was slowly bubbled. The d.o.t. was measured with an oxygen electrode (type MG2; Biolafitte, France) and was kept constant during growth by automatically varying the agitation speed (controller unit made by Applikon, Vlaardingen, The Netherlands). Some growth experiments were carried out in a 71 fermenter (model 19; New Brunswick Scientific Co.). The d.o.t. was then measured with a New Brunswick oxygen electrode (M IO16-0201) and maintained at a constant level by automatically varying the agitation speed (dissolved oxygen controller model DO-82, New Brunswick). D.o.t. fluctuations were $\pm 0.01 \mathrm{~atm}$, at the most. The inoculum was a culture of $C$. sputorum grown in TL medium supplemented with I $g$ $\mathrm{KNO}_{3} \mathrm{I}^{-1}$ at $37^{\circ} \mathrm{C}$ for $40 \mathrm{~h}$ in an anaerobic jar containing an atmosphere of $\mathrm{N}_{2}$ plus $5 \% \mathrm{CO}_{2}$. The growth of cultures was followed turbidimetrically at $660 \mathrm{~nm}$. Dry weights were measured by membrane filtration as described by de Vries \& Stouthamer (1968).

Determination of lactate and other products in supernatant fluids. L-Lactate and D-lactate were measured enzymically by the methods of Hohorst (1970) and Gahwehn \& Bergmeyer (1970), respectively. Acetate was determined by the enzymic method of Rose et al. (1954), which is based on the colorimetric determination of acetyl phosphate according to Lipmann \& Tuttle (1945). Pyruvate was measured enzymically with lactate dehydrogenase according to van Gent-Ruijters, de Vries \& Stouthamer (1975). Succinate was measured as the methyl derivative (Holdeman \& Moore, 1972) by gas-liquid chromatography as described by van Gent-Ruijters et al. (1975). Formate was measured by the method of Lang \& Lang (1972).

Preparation of bacterial suspensions and extracts. Bacterial suspensions were prepared by harvesting the cells and washing them twice with a chilled 67 mM-sodium potassium phosphate buffer, $\mathrm{pH} 6.8$, through which $\mathrm{N}_{2}$ had been bubbled for at least $\mathrm{I} h$. Extracts were prepared by disrupting bacteria suspended in this buffer with an MSE ultrasonic power unit for three I min periods. The resulting material was centrifuged at $6000 \mathrm{~g}$ for $20 \mathrm{~min}$. Bacterial suspensions and extracts were stored in liquid nitrogen. Protein was measured by the method of Lowry et al. (195I) using bovine serum albumin as a standard.

Measurement of enzyme activities in bacterial suspensions and extracts. Oxygen consumption by bacterial suspensions before and after addition of the substrate (final concentration Io $\mathrm{mm}$ ) was followed polarographically at $37^{\circ} \mathrm{C}$ in the biological oxygen monitor, model 53 (Yellow Springs Instrument Co., Yellow Springs, Ohio, U.S.A.). The electrode was calibrated with air-saturated distilled water assumed to contain $215 \mathrm{nmol} \mathrm{O}_{2} \mathrm{ml}^{-1}$ at $37^{\circ} \mathrm{C}$. NADH and NADPH oxidase activities in extracts were measured at $25^{\circ} \mathrm{C}$ from the decrease in extinction at $339 \mathrm{~nm}$ after adding the respective substrates (final concentration $0.14 \mathrm{~mm}$ ). The value given by Bergmeyer (1975) for the molar extinction coefficients of NADH and NADPH at $339 \mathrm{~nm}$ was used $\left(6300 \mathrm{M}^{-1} \mathrm{~cm}^{-1}\right)$. Lactate dehydrogenase was assayed spectrophotometrically at $600 \mathrm{~nm}$ with 2,6-dichlorophenolindophenol (2,6-DCIP) at $25^{\circ} \mathrm{C}$ in an assay mixture $(2.75 \mathrm{ml})$ containing: $60 \mathrm{~mm}$ sodium potassium phosphate buffer, $\mathrm{pH} 6.8 ; 0.08 \mathrm{mM}-2,6-\mathrm{DCIP}$; bacterial suspension or extract, $\mathrm{O} \cdot \mathrm{I}$ to $0.5 \mathrm{mg}$ protein. Succinate dehydrogenase was assayed in the same way except that the buffer in this assay contained I mM- $\mathrm{MgCl}_{2}$ and I mM-KCN. The reaction was started by adding $50 \mu \mathrm{mol}$ sodium lactate or sodium succinate, respectively. 


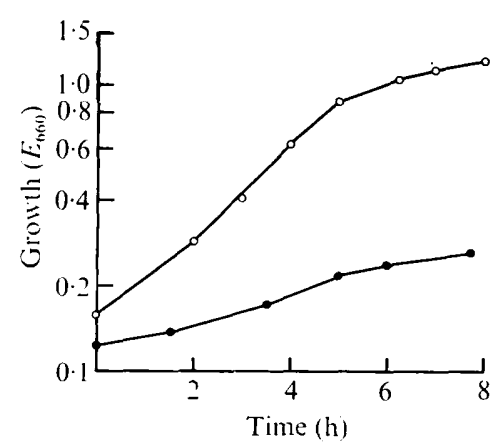

Fig. I

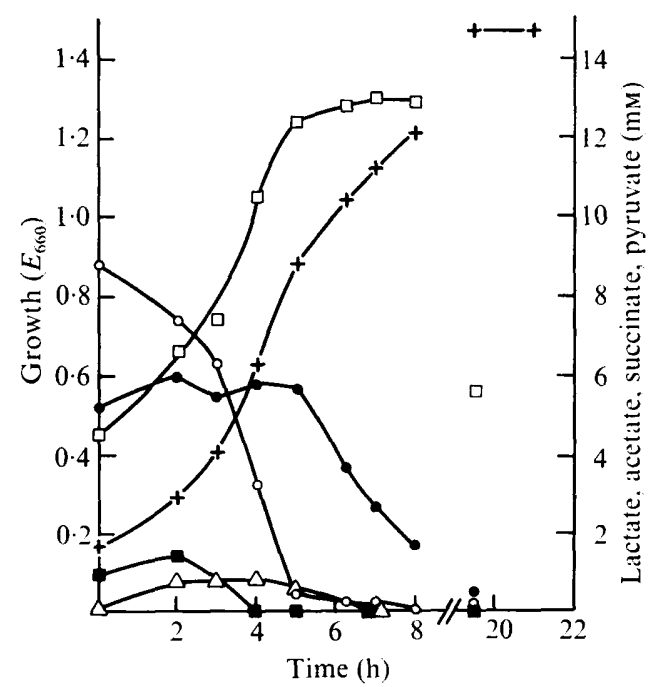

Fig. 2

Fig. I. Growth of $C$. sputorum subsp. bubulus at different dissolved oxygen tensions: $0,0.025$ atm; $0,0.15 \mathrm{~atm}$.

Fig. 2. Consumption and production of several substances by $C$. sputorum subsp. bubulus growing at a d.o.t. of 0.025 atm. +, Growth; $O$, L-lactate; 0 , D-lactate; $\square$, acetate; $\square$, succinate; $\triangle$, pyruvate.

Measurement of difference spectra. Reduced minus oxidized difference spectra of bacterial suspensions were recorded with an Aminco DW-2 u.v./vis spectrophotometer (American Instruments Co., Washington, U.S.A.). Cytochrome $c$ was estimated from dithionite-reduced minus air-oxidized difference spectra by using the extinction coefficient given by Kröger \& Innerhofer (1976) for the extinction difference between the maximum at $553 \mathrm{~nm}$ and the minimum at $540 \mathrm{~nm}\left(\epsilon=25100 \mathrm{M}^{-1} \mathrm{~cm}^{-1}\right)$. Low-temperature spectra of bacterial suspensions containing $40 \%(\mathrm{v} / \mathrm{v})$ glycerol were recorded at $-196{ }^{\circ} \mathrm{C}$. (Dithionite-reduced plus $\mathrm{CO}$ ) minus dithionite-reduced difference spectra of bacterial suspensions were recorded after bubbling $\mathrm{CO}$ through the sample cuvette for $4 \mathrm{~min}$. An acid acetone extraction, as described by Cole \& Rittenberg (1971), was performed on bacterial suspensions prepared from organisms that had been grown at a d.o.t. of 0.025 atm to an extinction of 0.6 . The bacterial suspensions contained approximately $30 \mathrm{mg}$ dry wt $\mathrm{ml}^{-1}$. The haems present in the extract and residue were determined from the dithionite-reduced minus air-oxidized difference spectra of their pyridine haemochromogens, using the extinction coefficients given by Kröger \& Innerhofer (1976) for the extinction difference between the maximum at $557 \mathrm{~nm}$ and the minimum at $540 \mathrm{~nm}$ (protohaem; $\epsilon=27300 \mathrm{M}^{-1} \mathrm{~cm}^{-1}$ ) and for the extinction difference between the maximum at $55 \mathrm{Im}$ and the minimum at $540 \mathrm{~nm}$ (haem $\mathrm{C} ; \epsilon=22100 \mathrm{M}^{-1} \mathrm{~cm}^{-1}$ ).

Chemicals. Thioglycollate medium (U.S.P.) was obtained from Oxoid. Tryptose broth was obtained from Difco. Sodium DL-lactate solution, containing $34 \%$ L-lactate and $27 \%$ D-lactate, and BES were obtained from BDH. Sodium L-lactate and lithium D-lactate were obtained from Serva, Entwicklungslabor, Heidelberg, Germany. NADH, NADPH, ATP, and all the enzymes used were obtained from Boehringer. 2,6-DCIP was purchased from Merck.

\section{RESULTS}

\section{Growth and lactate conversion at different dissolved oxygen tensions}

Campylobacter sputorum subsp. bubulus 9977 grew well in TL medium at a d.o.t. of $0.025 \mathrm{~atm}$ (Fig. I). The generation time increased steadily from approximately $\mathrm{I} .5 \mathrm{~h}$ at a d.o.t. of $0.002 \mathrm{~atm}$ to about $2.0 \mathrm{~h}$ at a d.o.t. of $0.05 \mathrm{~atm}$, but the final extinction after $20 \mathrm{~h}$ remained fairly constant. When d.o.t. during growth was maintained at a value exceeding $0.05 \mathrm{~atm}$, the growth rate decreased considerably (Fig. I). During exponential growth at a d.o.t. of $0.025 \mathrm{~atm}$, for each mol L-lactate that was consumed, $\mathrm{I} \cdot 0 \mathrm{~mol}$ acetate was formed (Fig. 2). For cultures in this growth phase $Y_{\text {tr-lactate }}$ (g dry wt bacteria per mol L-lactate) was 54. Slow growth of $C$. sputorum was observed in the absence of lactate and, when this 


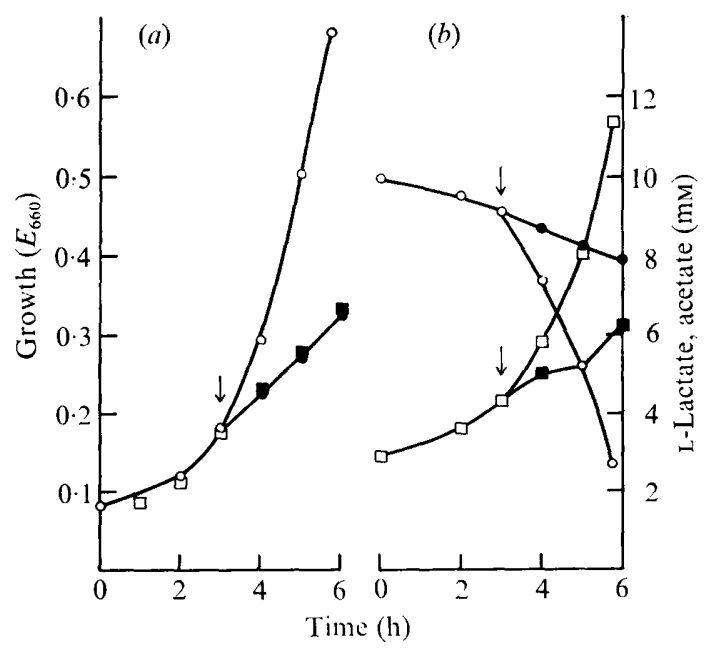

Fig. 3. Effect of a sudden increase in the dissolved oxygen tension on growth (a) and L-lactate consumption and acetate production $(b)$ by $C$. sputorum subsp. bubulus. D.o.t. was kept constant at $0.02 \mathrm{~atm}$ (open symbols) or, where indicated by the arrows, raised to $0.15 \mathrm{~atm}$ (closed symbols). (a) $\mathrm{O}, \odot$, Growth in TL-medium; $\square, \square$, growth in BES-buffered TL medium containing $0.6 \mathrm{~g}$ $\mathrm{FeCl}_{3} .6 \mathrm{H}_{2} \mathrm{O}^{-1}$. (b) $\mathrm{O}, 0, \mathrm{~L}$-Lactate; $\square, \square$, acetate.

Table I. Oxidase and dehydrogenase activities in C. sputorum subsp. bubulus

Suspensions were prepared from organisms grown at a d.o.t. of 0.02 atm for $6 \mathrm{~h}$. In the shift experiments, the d.o.t. was raised from 0.02 to 0.15 atm $3 \mathrm{~h}$ after inoculation, and growth was continued for another $3 \mathrm{~h}$ before suspensions were prepared. Enzyme activities were measured in these bacterial suspensions as described in Methods, except NADH and NADPH oxidase activities which were determined in extracts.

Substrate
$\mathrm{Na}$ DL-lactate
$\mathrm{Na}$-lactate
$\mathrm{Li}$ D-lactate
$\mathrm{Na}$ succinate
$\mathrm{Na}$ formate
$\mathrm{Na}$ acetate
$\mathrm{Na}$ pyruvate
$\mathrm{NADH}$
$\mathrm{NADPH}$

Oxidase activity [nmol $\mathrm{O}_{2}$ uptake min $^{-1}$ (mg protein $\left.)^{-1}\right]$

$\begin{array}{cc}\text { No shift } & \text { Shift } \\ \text { I8 } & 2 \\ 15 & \text { I } \\ \text { I9 } & \text { I } \\ 8 & 5 \\ 870 & 460 \\ \text { O.I } & 0 \cdot I \\ \text { O.I } & 0 \cdot 1 \\ 14 & 7 \\ 8 & 9\end{array}$

Dehydrogenase activity [nmol 2,6-DCIP reduced $\left.\min ^{-1}(\text { mg protein })^{-1}\right]$

$\begin{array}{cc}\text { No shift } & \text { Shift } \\ \text { I3 } & 2 \\ \text { I I } & \text { I } \\ \text { I5 } & \text { I } \\ \text { I } 8 & 8 \\ \text { ND } & \text { ND } \\ \text { ND } & \text { ND } \\ \text { ND } & \text { ND } \\ \text { ND } & \text { ND } \\ \text { ND } & \text { ND }\end{array}$

ND, Not determined.

was taken into account, $Y_{\mathrm{L}-\text { lactate }}$ was approximately halved. When L-lactate had been almost completely utilized, $C$. sputorum started to consume D-lactate; this coincided with a reduction in the growth rate. At that same time the rate of acetate production slowed down and eventually halted. If the incubation was continued for about $\mathrm{Io} h$, a considerable decrease of the acetate concentration in the medium was observed. The succinate present at the beginning of the incubation came almost entirely from the inoculum; the concentration initially increased, but later decreased, until after $4 \mathrm{~h}$ it could not be detected. Pyruvate in the growth medium showed similar behaviour. The formate concentration in the growth medium never exceeded $0.8 \mathrm{~mm}$ (result not shown). Identical results were obtained when $C$. sputorum grew at any other d.o.t. that allowed good growth.

To investigate what changes occur when $C$. sputorum is exposed to a d.o.t. higher than 
$0.05 \mathrm{~atm}$, a culture was grown at a d.o.t. of $0.02 \mathrm{~atm}$ to an extinction of about 0.15 and then the d.o.t. was raised to $0.15 \mathrm{~atm}$. The transition took $10 \mathrm{~min}$, after which time the d.o.t. was kept constant during further growth. After the shift, the bacteria continued to grow for at least $3 \mathrm{~h}$ but at a much slower rate than when they were allowed to continue their growth at a d.o.t. of $0.02 \mathrm{~atm}$ (Fig. $3 a$ ). The rate of L-lactate consumption and corresponding acetate production decreased after the shift in d.o.t. (Fig. $3 b$ ). D-Lactate was not utilized in this period. In the culture subjected to a shift in d.o.t., succinate was still present after $6 \mathrm{~h}$. The pyruvate concentration was not significantly influenced by the shift, nor did formate accumulation occur at the high d.o.t. (results not shown). The reduction in the growth rate by a shift to an unfavourable d.o.t. was not prevented by raising the $\mathrm{FeCl}_{3} \cdot 6 \mathrm{H}_{2} \mathrm{O}$ concentration in the medium to $0.6 \mathrm{~g} \mathrm{l}^{-1}$ (Fig. $3 a$ ).

\section{Enzyme activities of cells grown at different dissolved oxygen tensions}

These results prompted us to determine some enzyme activities of suspensions of $C$. sputorum before, and $3 \mathrm{~h}$ after, a shift to an unfavourable d.o.t. When growth was at a d.o.t. of $0.02 \mathrm{~atm}$ at the expense of L-lactate and organisms were harvested at 3 or $6 \mathrm{~h}$ after inoculation, enzyme activities were essentially the same. Bacterial suspensions oxidized L- and D-lactate and succinate, and a very powerful formate oxidase activity was observed (Table I). Acetate and pyruvate caused a marginal stimulation of respiration. When cells had been exposed to a d.o.t. of $0.15 \mathrm{~atm}$ between 3 and $6 \mathrm{~h}$ after inoculation, the enzyme activities were lower, lactate oxidase and dehydrogenase activities being affected most (Table I). The decrease was observed whether DL-lactate or the D- or L-isomer was used as substrate. The fact that the percentage decrease in activity was almost the same for lactate oxidase and lactate dehydrogenase is an indication that the main harmful action of oxygen is exerted on lactate dehydrogenase rather than on the cytochrome system.

In extracts of organisms grown at a d.o.t. of 0.02 atm both lactate and succinate dehydrogenase specific activities were very similar to those observed in bacterial suspensions [I4 and $30 \mathrm{nmol} 2,6$-DCIP reduced $\min ^{-1}$ (mg protein) ${ }^{-1}$, respectively]. A shift in d.o.t. to $0.15 \mathrm{~atm}$ decreased these activities to the same extent as in bacterial suspensions. After centrifuging the bacterial extract at $\mathrm{I} 44000 \mathrm{~g}$ for $\mathrm{I} \cdot 5 \mathrm{~h}, 80$ to $90 \%$ of the lactate dehydrogenase activity was found in the pellet, indicating that it is a membrane-bound enzyme. NADH oxidase activity was halved by a shift in d.o.t. from 0.02 to $0.15 \mathrm{~atm}$, whereas NADPH oxidase was unaffected by such a shift (Table I).

\section{Cytochrome content of Campylobacter sputorum subspecies bubulus}

Campylobacter sputorum subsp. bubulus contains cytochromes of the $b$ - and $c$-type (Fig. 4). At $25{ }^{\circ} \mathrm{C}$ reduced minus oxidized difference spectra of bacterial suspensions showed peaks at 553,523 and $426 \mathrm{~nm}$ and a shoulder of the $\beta$-peak at 530 to $531 \mathrm{~nm}$. In difference spectra recorded at $-196^{\circ} \mathrm{C}$, the $\alpha$-peak split into two peaks at 550 and $553 \mathrm{~nm}$. The amount of cytochrome $c$ present in $C$. sputorum, harvested in the exponential phase of growth at a d.o.t. of $0.025 \mathrm{~atm}$, was calculated to be $0.85 \mathrm{nmol}$ cytochrome $c$ per $\mathrm{mg}$ dry wt. The cytochrome $c$ content did not change significantly after a shift in d.o.t. to $0.15 \mathrm{~atm}$ nor did the entire cytochrome spectrum. The pyridine haemochromogens of the two types of cytochromes separated by an acid acetone extraction showed peaks at the following wavelengths in dithionite-reduced minus air-oxidized difference spectra: haem C, 55I, 521 and $416 \mathrm{~nm}$; protohaem, 557,526 and $420 \mathrm{~nm}$. From these spectra we calculated that there were $0.58 \mathrm{nmol}$ cytochrome $c$ and 0.1 I nmol cytochrome $b$ per $\mathrm{mg}$ dry wt cells grown at a d.o.t. of $0.025 \mathrm{~atm}$.

By recording a (reduced plus $\mathrm{CO}$ ) minus reduced difference spectrum, the presence of a CO-binding pigment was demonstrated (Fig. 5). Peaks were found at 570,538 and $414 \mathrm{~nm}$ and troughs at 553,523 and $432 \mathrm{~nm}$. From these results we cannot distinguish whether this CO-binding pigment is cytochrome $o$ or a CO-binding $c$-type cytochrome like those tabulated by Weston \& Knowles (1973). 


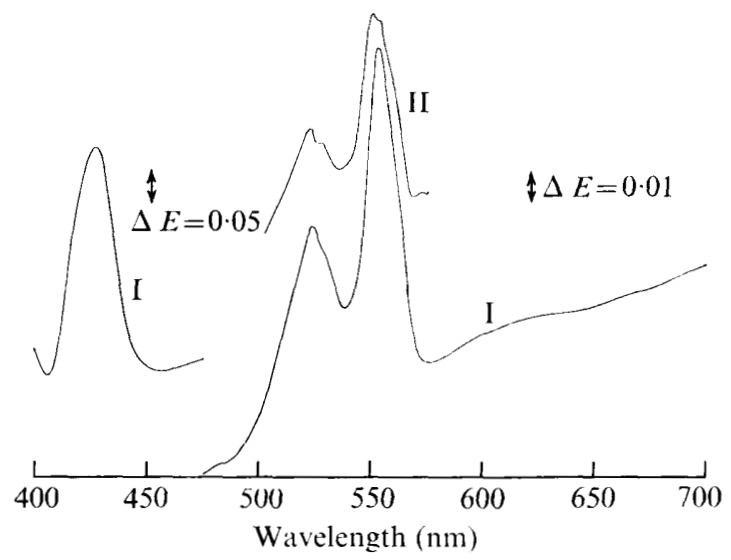

Fig. 4. Dithionite-reduced minus oxygen-oxidized difference spectra of a suspension of $C$. sputorum subsp. bubulus, grown at a d.o.t. of $0.02 \mathrm{~atm}$. Spectra were recorded at $25^{\circ} \mathrm{C}$ (I) and $-196^{\circ} \mathrm{C}$ (II). Bacterial suspensions contained $3.6 \mathrm{mg}$ protein $\mathrm{ml}^{-1}$ (I) and 9.0 $\mathrm{mg}$ protein $\mathrm{ml}^{-1}$ (II).

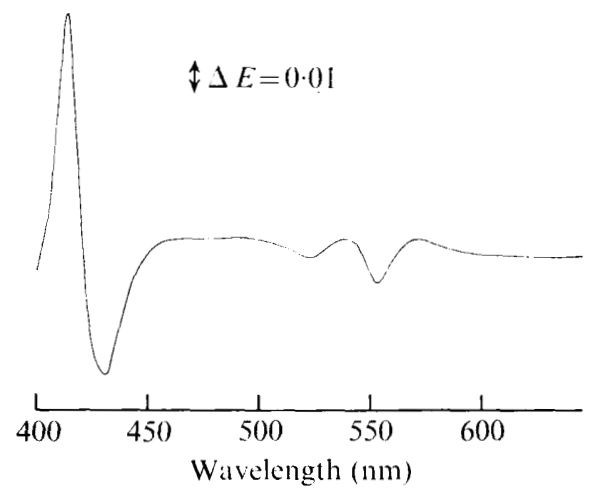

Fig. 5. (Reduced plus CO) minus reduced difference spectrum of a suspension of C. sputorum subsp. bubulus, grown at a d.o.t. of 0.025 atm. The suspension contained $2.8 \mathrm{mg}$ dry wt $\mathrm{ml}^{-1}$.

\section{DISCUSSION}

For exponential growth of C. sputorum subsp. bubulus, the presence of L-lactate in the growth medium is essential. This supports the assumption that L-lactate is the only energy source used in TL medium during the period of growth from which a $Y_{\mathrm{L} \text {-lactate }}$ value ( $\mathrm{g}$ dry wt bacteria per mol L-lactate) of 54 was calculated. This value is much too high to be explained by substrate-level phosphorylation only, so, in addition to ATP generated by substrate-level phosphorylation on the formation of acetate, C. sputorum must derive energy from oxidative phosphorylation in the electron transfer system from lactate to oxygen. Even if growth of $C$. sputorum in the absence of DL-lactate is taken into account, this conclusion is still valid. The presence of a powerful formate oxidase activity may indicate that formate is formed as an intermediate at pyruvate conversion. Whether energy is gained by the oxidation of formate is still a question to be answered, although it is known that formate can stimulate growth of C. sputorum (Syed \& Loesche, 1971).

The preferential consumption of L-lactate, though both L-lactate and D-lactate oxidase are active, suggests a possible regulatory role of $\mathrm{L}$-lactate on D-lactate utilization. The presence of L-lactate in the growth medium also prevents utilization of acetate.

Loesche et al. (1965) found that $C$. sputorum strain 9977, used in this investigation, exhibited optimal growth on agar slants in an atmosphere containing 0.1 atm $\mathrm{O}_{2}$, growth being impaired at lower oxygen tensions. The fact that we observed constant growth rates 
and yields at d.o.t. ranging from 0.002 to $0.05 \mathrm{~atm}$, while both decreased at higher d.o.t., is not necessarily in contradiction with the results of Loesche et al. (1965), because the measured parameters are not the same: the d.o.t. in a growing culture in our experiments and the oxygen tension of the applied gas mixture in those of Loesche et al. Increasing the $\mathrm{FeCl}_{3}$ concentration in the growth medium did not protect $C$. sputorum against the growth inhibiting effect of a shift to an unfavourably high d.o.t. This behaviour contrasts with that of the catalase-positive organism Campylobacter fetus subsp. jejuni, growing on solid medium for 5 days (Bowdre et al., I976).

In the present investigation we were concerned with the possible intracellular targets of oxygen in C. sputorum. Previously identified targets are cytochrome synthesis (ClarkWalker, Rittenberg \& Lascelles, 1967; Sinclair \& White, 1970; de Vries, van WijckKapteyn \& Stouthamer, 1972) and/or synthesis of catabolic enzymes (Cole, 1973; van Gent-Ruijters et al., 1976). In C. sputorum the cytochrome content did not change significantly after a shift to an unfavourable d.o.t. Inhibition of growth could be attributed to a decreased ability to use lactate as energy source. From measurements of enzyme activities (see Table I) evidence was obtained that the primary oxygen damage is to lactate dehydrogenase rather than to the cytochrome chain. This was confirmed by dual wavelength experiments in which the reduction of cytochrome $c$ by lactate was followed (results not shown). We are planning to investigate further the electron transfer chain and energy metabolism of $C$. sputorum subsp. bubulus and the effect of the d.o.t. on these.

We are grateful to Dr W. H. van Palenstein Helderman for the gift of Campylobacter sputorum subsp. bubulus.

\section{REFERENCES}

Bergmeyer, H. U. (1975). Neue Werte für die molaren Extinktions-Koeffizienten von NADH und NADPH zum Gebrauch im RoutineLaboratorium. Zeitschrift für Klinische Chemie und Klinische Biochemie 13, 507-508.

Bowdre, J. H., KRIEG, N. R., HofFMAN, P. S. \& SMIBERT, R. M. (1976). Stimulatory effect of dihydroxyphenyl compounds on the aerotolerance of Spirillum volutans and Campylobacter fetus subspecies jejuni. Applied and Environmental Microbiology 31, 127-133.

Clark-Walker, G. D., Rittenberg, B. \& LasCELles, J. (1967). Cytochrome synthesis and its regulation in Spirillum itersonii. Journal of Bacteriology 94, I648-1655.

Cole, J. A. (1973). Abnormally low activities of fumarate hydratase and malate dehydrogenase in oxygen-sensitive cultures of Spirillum volutans. Journal of General Microbiology 78, 371-374.

Cole, J. A. \& Rittenberg, S.C. (1971). A comparison of respiratory processes in Spirillum volutans, Spirillum itersonii, and Spirillum serpens. Journal of General Microbiology 69, 375-383.

GAHWEHN, K. \& BeRGMEYER, H. U. (1970). In Methoden der Enzymatischen Analyse, vol. 2, pp. 1450-1453. Edited by H. U. Bergmeyer. Weinheim, Germany: Verlag Chemie.

VAN Gent-RuiJTers, M. L. W., DE Meyere, F. A., DE VRIES, W. \& Stouthamer, A. H. (I976). Lactate metabolism in Propionibacterium pentosaceum growing with nitrate or oxygen as hydrogen acceptor. Antonie van Leeuwenhoek 42, 217 228.

van Gent-RuiJters, M. L. W., DE VRies, W. \& STOUTHAMFR. A. H. (1975). Influence of nitrate on fermentation pattern, molar growth yields and synthesis of cytochrome $b$ in Propionibacterium pentosaceum. Journal of General Microbiology 88, 36-48.

HOHORST, H.-J. (1970). In Methoden der Enzymatischen Analyse, vol. 2, pp. I425-1429. Edited by H. U. Bergmeyer. Weinheim, Germany: Verlag Chemie.

Holdeman, L. V. \& MoORe, W. E. C. (1972). Anaerobe Laboratory Manual. Blacksburg, Virginia, U.S.A.: Virginia Polytechnic Institute and State University.

KRöGER, A. \& INNERHOFER, A. (1976). The function of the $b$ cytochromes in the electron transport from formate to fumarate of Vibrio succinogenes. European Journal of Biochemistry 69, 497-506.

LANG, E. \& LANG, H. (1972). Spezifische Farbreaktion zum direkten Nachweis der Ameisensäure. Zeitschrift für Analytische Chemie 260, 8-10.

LipmanN, F. \& TutTle, L. C. (I945). A specific micromethod for the determination of acylphosphates. Journal of Biological Chemistry 159, 2I-28.

Loesche, W. J., Gibbons, R. J. \& Socransky, S. S. (1965). Biochemical characteristics of Vibrio sputorum and relationship to Vibrio bubulus and Vibrio fetus. Journal of Bacteriology 89, I109III6.

Lowry, O. H., Rosebrough, N. J., Farr, A. L. \& Randall, R. J. (I95I). Protein measurement with the Folin phenol reagent. Journal of Biological Chemistry 193, 265-275.

Niekus, H. G. D., DE VRIES, W. \& Stouthamer, A. H. (1977). Growth of Campylobacter sputorum subspecies bubulus in batch cultures at different dissolved oxygen tensions. Proceedings of the Society for General Microbiology 4, 76. 
van Palenstein Helderman, W. H. \& Rosman, I. (1976). Hydrogen-dependent organisms from the human gingival crevice resembling Vibrio succinogenes. Antonie van Leeuwenhoek 42, 107-1 18.

Rose, I. A., GrunberG-Manago, M., Korey, S. R. \& OCHOA, S. (1954). Enzymatic phosphorylation of acetate. Journal of Biological Chemistry 2rr, 737-756.

Sebald, M. \& Véron, M. (1963). Teneur en bases de l'ADN et classification des vibrions. Annales de l'Institut Pasteur 105, 897-9 I0.

Sinclair, P. R. \& WhITE, D. C. (1970). Effect of nitrate, fumarate, and oxygen on the formation of the membrane-bound electron transport system of Haemophilus parainfluenzae. Journal of Bacteriology ror, 365-372.
Syed, S. A. \& LOESCHE, W. J. (I97r). Similarity of microaerophilic vibrios and Vibrio succinogenes. Bacteriological Proceedings, 54.

de Vries, W. \& Stouthamer, A. H. (1968). Fermentation of glucose, lactose, galactose, mannitol, and xylose by bifidobacteria. Journal of Bacterio$\log y$ 96, 472-478.

DE VRIES, W., VAN WiJCK-Kapteyn, W. M. C. \& Stouthamer, A. H. (1972). Influence of oxygen on growth, cytochrome synthesis and fermentation pattern in propionic acid bacteria. Journal of General Microbiology 71, 5I 5-524.

Weston, J. A. \& Knowles, C. J. (1973). A soluble CO-binding $c$-type cytochrome from the marine bacterium Beneckea natriegens. Biochimica et biophysica acta 305, I I-I 8 . 